\title{
Brain Response to Protein Undernutrition
}

\author{
MECHANISM OF PREFERENTIAL PROTEIN RETENTION
}

\author{
Peter R. Dalliman and Robert A. Spirito \\ From the Department of Pediatrics, School of Medicine, University of \\ California, San Francisco, California 94122
}

\begin{abstract}
A B S T RACT This study was designed to determine how the brain, in contrast to most other tissues, maintains an almost normal protein content during a period of dietary protein deficiency. Administration of leucine- ${ }^{-} \mathrm{H}$ to rats was started during a period of early development (6-18 days) which is characterized by disproportionately rapid brain growth; later (24-33 days) leucine- ${ }^{14} \mathrm{C}$ was administered, when brain growth diminishes but total body weight gain continues to be rapid. At 35 days of age the ratio of ${ }^{3} \mathrm{H}:{ }^{14} \mathrm{C}$ in cerebrum, cerebellum, and brain stem protein averaged between 1.63 and 1.82. In skeletal muscle, liver, myocardium, and intestinal mucosa the mean ${ }^{8} \mathrm{H}:{ }^{14} \mathrm{C}$ was 1.07 or less. Then, a diet containing either $26 \%$ or $3.4 \%$ protein was administered. In animals fed the $26 \%$ protein diet, ${ }^{3} \mathrm{H}:{ }^{14} \mathrm{C}$ in the three brain segments remained essentially unchanged over a 42 day period. In contrast, in the $3.4 \%$ protein group ${ }^{8} \mathrm{H}:{ }^{14} \mathrm{C}$ in brain decreased to values approaching those of other tissues in the body: cerebrum, 1.18; cerebellum, 1.20 ; and brain stem, 1.16. The results suggest that conservation of brain protein is not due entirely to the long life-span of its cellular components or to efficient reutilization of the products of protein catabolism but through utilization of amino acids from degradation of protein elsewhere in the body.
\end{abstract}

\section{INTRODUCTION}

Starvation and protein-calorie undernutrition result in a decreased rate of growth or loss of total body weight (1). However, the effect on individual organs and cell types is far from uniform (2-6). Skeletal muscle and liver account for a major portion of the weight deficit under most conditions of undernutrition, whereas other tissues, such as brain, appear to be spared. The factors responsible for the relatively protected status of the

Received for publication 12 October 1971 and in revised form 7 February 1972. brain in respect to size and protein content are not yet defined.

Certain characteristics of growth and development of the brain could account for its relative resistance to the effects of undernutrition. Brain growth is disproportionately rapid during early development (7), particularly in the intrauterine and nursing periods which are also characterized by the best assurance of adequate nutrition from maternal sources. At weaning, the brain weight and cell number in most mammals is close to that of the adult (7). The effects of malnutrition are often most profound in rapidly growing tissues (5) and, in fully grown animals, in those tissues with a rapid rate of cell replacement such as blood, intestinal mucosa, and epithelial tissues $(8,9)$. There is very little cell proliferation or cell replacement in the adult brain (10).

An additionial factor favoring the retention of protein by the brain is that many cellular components of nervous tissue, particularly nerve collagen and lipoprotein fractions of brain, appear to have a long lifespan-in excess of 150 days in the rat $(11,12)$. Thus, the requirement for dietary substrates to replace loss of degraded protein components of these cells should be much less than in an organ such as the liver which, in spite of a slow rate of cell renewal, replaces over half of its protein in less than 4 days (13).

Increased reutilization of cellular breakdown products is also an extremely efficient adaptation to malnutrition. In rats fasted 1 or 2 days, as much as $90 \%$ of the free amino acid pool available for synthesis of new protein in liver is reported to be derived from protein degradation (14). Other investigators (15), using similar methods, report less striking effects of starvation or low protein diet on the recycling of amino acids.

A different mechanism by which brain protein can be spared when the normal dietary sources are interrupted or diminished, is through a supply of amino acids to the brain from such tissues as liver and skeletal muscle (14, 
16). In starved rats, liver weight and protein decrease drastically for 2-3 days and then stabilize $(14,17)$. This period is followed by a slow but sustained loss of weight and protein by the skeletal muscle (14). It is uncertain whether the protein is mobilized primarily to satisfy energy needs or whether it also supplies the raw materials for maintaining the integrity of such tissues as brain that are characterized by very little weight deficit during malnutrition.

Our study suggested itself as a means of assessing the extent to which the brain maintains itself during a period of protein malnutrition, either by conservation of its cellular protein constituents or, alternately, through preferential utilization of amino acids released by other tissues in the body. It was anticipated that administration of leucine- ${ }^{3} \mathrm{H}$ to rats during a period of early development characterized by disproportionately rapid brain growth, and leucine- ${ }^{14} \mathrm{C}$ later, when brain growth diminishes but total body weight gain remains rapid, would result in labeling of brain protein with a uniquely high ratio of ${ }^{3} \mathrm{H}:{ }^{14} \mathrm{C}$. After institution of a diet low in protein, it would then be determined whether brain protein retains this labeling ratio or reverts to one characteristic of other body proteins.

\section{METHODS}

Female Sprague-Dawley rats ${ }^{1}$ were housed eight per litter at 6 days of age together with mothers, under conditions of controlled temperature and a 7 a.m. to 7 p.m. light cycle. The mothers were fed a complete pelleted diet. ${ }^{2}$ Nursing animals were kept with the mothers until 20 days of age, then weaned and housed four per cage and fed the pelleted diet until 35 days of age. After this the rats were divided into two groups, one fed a $26 \%$ protein diet and the other a protein-deficient diet $(3.4 \%)^{3}$. Food and drinking water were available continuously.

Injections of radioisotopes "were given intraperitoneally between 2 and 4 p.m. L-Leucine-[4,5- $\left.{ }^{3} \mathrm{H}\right]$ was given daily in a dose of $10 \mu \mathrm{Ci} / 100 \mathrm{~g}$ body weight $(40 \mathrm{Ci} / \mathrm{mmole})$ for 13 days, from 6 through 18 days of age; L-leucine- $\left[{ }^{14} \mathrm{C}\right] 1.0$ $\mu \mathrm{Ci} / 100 \mathrm{~g}$ ( $300 \mathrm{Ci} / \mathrm{mmole})$ was injected daily for 10 days, from ages 24 through 33 days. Individual rats received an average total of $22 \mu \mathrm{Ci}$ leucine- ${ }^{3} \mathrm{H}$ and $7.3 \mu \mathrm{Ci}$ leucine ${ }^{-14} \mathrm{C}$.

Randomly selected groups of rats were killed by decapitation between 9 and 10 a.m., before institution of the low protein and normal protein diet regimens at 35 days of age, and after $3,10,20$, and 42 days of the diet, corresponding to $38,45,55$, and 77 days of age, respectively. The organs were quickly excised and frozen, or immediately weighed and homogenized in cold distilled water in a Potter-Elvehjem glass homogenizer. The homogenate was adjusted to $1: 10, \mathrm{w} / \mathrm{v}$, with water. Intestinal mucosa was

\footnotetext{
${ }^{1}$ Obtained from Simonsen Laboratories, Gilroy, Calif.

- Berkeley Diet-Rat and Mouse Food. Feedstuffs Processing Co., San Francisco, Calif.

${ }^{8}$ Normal protein test diet, $26 \%$ protein (No. 170590) and low protein test diet, $3.4 \%$ protein (No. 170580). General BioChemicals, Chagrin Falls, Ohio.
}

‘ Schwarz Bio Research Inc., Orangeburg, N. Y. isolated from the second of four segments of equal length between the pylorus and the ileocecal junction.

Protein was precipitated with an equal volume of $10 \%$ cold trichloroacetic acid (TCA) and thoroughly washed once with 5\% TCA. Four additional washes resulted in no significant change in specific activity of protein. The washed pellet was hydrolyzed in $0.2 \mathrm{M} \mathrm{NaOH}$. The clear hydrolysate was used for determination of protein concentration by the method of Lowry, Rosebrough, Farr, and Randall (18), and for measurements of radioactivity. $\mathrm{NaOH}$ was not present in sufficient concentrations to interfere with the protein determination.

Radioactivity was measured in a Nuclear-Chicago Liquid Scintillation Counter, Unilux II. ${ }^{5}$ A $0.2 \mathrm{ml}$ portion of the protein hydrolysate was mixed with $1.0 \mathrm{ml}$ NCS protein solubilizer $^{5}$ and $10 \mathrm{ml}$ of a toluene-based scintillation mixture. Channels were selected that contained essentially no ${ }^{3} \mathrm{H}$ counts in the ${ }^{14} \mathrm{C}$ window and approximately $11 \%$ of the ${ }^{14} \mathrm{C}$ counts in the ${ }^{8} \mathrm{H}$ window. Efficiency of ${ }^{14} \mathrm{C}$ counting was $52 \%$ and that of ${ }^{3} \mathrm{H}$ was $22 \%$. Internal standards showed no significant differential quenching.

The radioactivity present in tissue homogenates was 90 95\% TCA precipitable. Incorporation of label into macromolecules other than protein in the TCA precipitate was determined as follows. Phospholipid was extracted by two washes with sodium acetate-saturated ethanol and a final wash in an ether-ethanol mixture $(1: 3 \mathrm{v} / \mathrm{v})$. The RNA was hydrolyzed by incubating the pellet $2 \mathrm{hr}$ in $0.3 \mathrm{~N} \mathrm{KOH}$ at $37^{\circ}$ and then extracted with $0.5 \mathrm{~N}$ percholoric acid (PCA). DNA was extracted by further incubating the pellet twice with $0.5 \mathrm{~N} \mathrm{PCA}$ at $70^{\circ}$ for $20 \mathrm{~min}$. No radioactivity was detected in the RNA fraction. Less than $25 \%$ of the total radioactivity was present in the DNA extract, but since a roughly corresponding amount of protein was also found to become solubilized in PCA during the $70^{\circ} \mathrm{C}$ incubation, this radioactivity most likely represents protein rather than significant incorporation into DNA. Negligible radioactivity was found in the phospholipid fraction of muscle or liver extracts. In contrast, the phospholipid fraction in brain homogenate (cerebrum) contained almost as much label as the protein fraction. However, there was no evidence of contamination of the $0.2 \mathrm{M} \mathrm{NaOH}$ protein hydrolysate by lipid radioactivity since prior lipid extraction had no effect on the counts in the protein fraction.

The proportion of label in protein remaining as leucine (or isoleucine) was determined by hydrolysis of acetone precipitated protein in $6 \mathrm{~N} \mathrm{HCl}$ at $110^{\circ}$ for $3 \mathrm{hr}$. A portion of the hydrolysate was spotted on $12 \times 12$ inch Whatman No. 3 filter paper and developed two-dimensionally in ascending manner on pyridine-acetone- $3 \mathrm{~N} \mathrm{NH}_{4} \mathrm{OH}(50: 30$ : $25)$ and isopropyl alcohol-formic acid- $\mathrm{H}_{2} \mathrm{O}(8: 1: 1)$. By this means some 15 amino acids could be separated; leucine and isoleucine migrate as one spot. The positions of the amino acids on the chromatogram were detected as blue regions by spraying with a $1 \%$ ethanolic ninhydrin solution. The same positions were marked on a second chromatogram developed along with the first and cut out. The amino acid "spots" were measured for radioactivity by placing the paper cut-outs directly in $10 \mathrm{ml}$ of scintillation mixture. All of the radioactivity on the chromatograms of the acidhydrolyzed protein of brain, liver, and muscle homogenates from both normal protein- and low protein-fed animals 20 days after cessation of isotope injection appeared in the leucine-isoleucine spot. None of the other amino acids separated contained any measurable activity.

\footnotetext{
${ }^{5}$ Nuclear-Chicago, Des Plaines, Ill.
} 


\section{RESULTS AND CONCLUSIONS}

Labeling pattern of protein in brain compared to other tissues. The design of this experiment required that brain protein attain a ratio of ${ }^{8} \mathrm{H}:{ }^{16} \mathrm{C}$ distinctly higher than in other tissues of the body, particularly such major depots of protein as skeletal muscle (6). Fig. 1 illustrates the basis for anticipating these results. Leucine- $-{ }^{8} \mathrm{H}$ was administered during a period of rapid increase in brain weight (19) and leucine $-{ }^{14} \mathrm{C}$ at a time when the rate of brain growth was decreasing but that of the rest of the body continued unabated. At 35 days of age, ${ }^{3} \mathrm{H}:{ }^{14} \mathrm{C}$ found in the protein of each of the three brain segments averaged between 1.63 and 1.82 (Table I) ; in all other tissues it was 1.07 or less. The ${ }^{8} \mathrm{H}:{ }^{14} \mathrm{C}$ ratio in brain was sufficiently higher than in other tissues to permit the planned experimental manipulations. As anticipated from their high rates of protein synthesis and degradation, liver (13) and intestinal mucosa (20) were particularly rich in ${ }^{14} \mathrm{C}$, the most recently administered isotope, resulting in the lowest ${ }^{8} \mathrm{H}:{ }^{14} \mathrm{C}$ ratio.

Body and tissue weights during administration of diets containing $3.4 \%$ or $26 \%$ protein. After institution of a $3.4 \%$ protein diet at 35 days of age body weight decreased slightly for 10 days but then remained essentially unchanged (Fig. 2). The increasing differ-

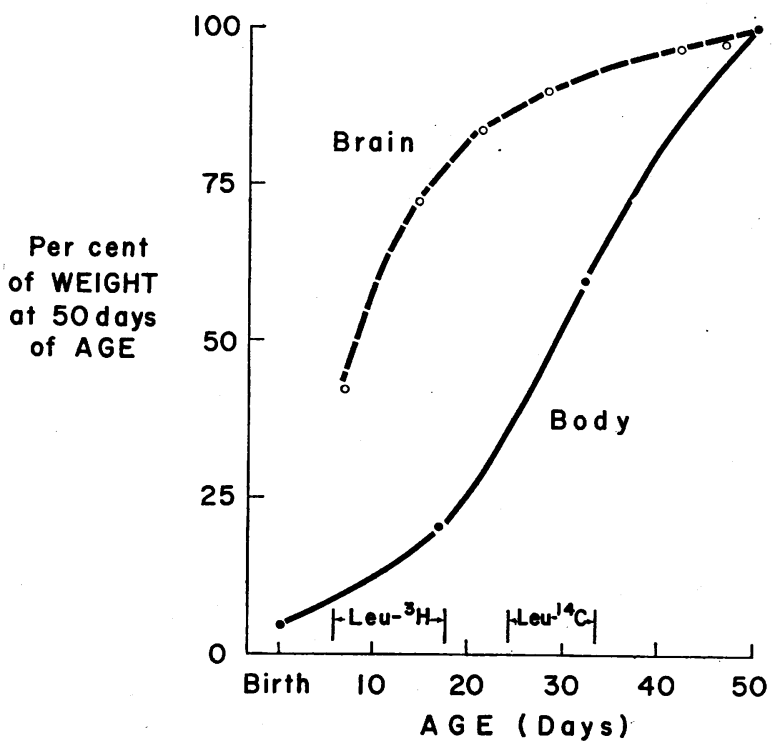

FIgure 1 Administration of leucine- ${ }^{8} \mathrm{H}$ and leucine- ${ }^{14} \mathrm{C}$ in relation to brain and body growth. The growth curves were derived from the data of Benton; Moser, Dodge, and Carr (19). L-Leucine- $\left[4,5^{3} \mathrm{H}\right]$ was given in daily intraperitoneal injections of $10 \mu \mathrm{Ci} / 100 \mathrm{~g}$ during a period of rapid brain growth, from 6 through 18 days, L-Leucine- $\left[{ }^{14} \mathrm{C}\right], 1 \mu \mathrm{Ci} / 100$ g per day, was similarly injected from ages 24 through 33 days, a period of rapid body growth but decreasing brain growth.
TABLE I

Labeling of Tissue Protein at 35 days of Age after Intraperitoneal Administration of L-Leucine- $\left[4,5^{3} \mathrm{H}\right], 10 \mu \mathrm{Ci} / 100 \mathrm{~g}$ Body

Weight Daily from 6 through 18 days of Age and L-Leucine-[14 $\mathrm{C}] 1 \mu \mathrm{Ci} / 100 \mathrm{~g}$ per day from 24

through 33 days of Age

\begin{tabular}{lccc}
\hline \multicolumn{1}{c}{ Tissue } & \multicolumn{1}{c}{${ }^{8 \mathrm{H}:{ }^{14} \mathrm{C}}$} & ${ }^{\mathrm{H}}$ & ${ }^{\mathrm{H}} \mathrm{C}$ \\
\hline Brain: & \multicolumn{3}{c}{$c p m / m g$ protein } \\
$\quad$ Cerebrum & $1.82 \pm 0.13^{*}$ & $372 \pm 34^{*}$ & $210 \pm 19^{*}$ \\
Cerebellum & $1.63 \pm 0.16$ & $432 \pm 15$ & $273 \pm 25$ \\
Brain stem & $1.77 \pm 0.16$ & $491 \pm 12$ & $286 \pm 21$ \\
Gastrocnemius & $1.07 \pm 0.10 \ddagger$ & $244 \pm 5$ & $228 \pm 17$ \\
Heart & $1.05 \pm 0.10 \ddagger$ & $219 \pm 5$ & $215 \pm 18$ \\
Liver & $0.38 \pm 0.058$ & $91 \pm 5$ & $243 \pm 28$ \\
\hline
\end{tabular}

* Means of 5 values \pm SEM.

$\ddagger$ Differs from cerebrum and brain stem, $P<0.01$ and from cerebellum, $P<0.02$.

\& Differs from cerebrum, cerebellum, and brain stem, $P<0.001$.

ence in weight between the protein-undernourished animals and control animals receiving $26 \%$ protein was due primarily to the continued growth of the latter group. Weight changes in skeletal muscle (gastrocnemius) were similar to those in body weight; however, there was little increase in liver weight in the $26 \%$ protein group after 45 days of age. Brain weight remained unchanged throughout the 42 day period of administration of the $3.4 \%$ protein diet. In animals which received the $26 \%$ protein diet, the brain grew only slightly until 45 days of age and remained $8-10 \%$ heavier than in the $3.4 \%$. protein rats $(0.1<P<0.2$ after 10 days, $P<0.01$ after 20 days and $0.05<P<$ 0.1 after 42 days of the dietary regimens). The concentration of protein in brain was essentially the same in the two groups between 35 and 77 days of age.

${ }^{8} \mathrm{H}:{ }^{14} \mathrm{C}$ in tissue protein during administration of diets containing $3.4 \%$ or $26 \%$ protein. In rats receiving the $26 \%$ protein diet, ${ }^{8} \mathrm{H}:{ }^{14} \mathrm{C}$ in the TCA-precipitable protein of the cerebrum, cerebellum, and brain stem remained essentially unchanged from the initial values at 35 days of age (Fig. 3). After 42 days of the $26 \%$ protein diet ( 77 days of age) the means of the ratios ranged from 1.64 to 1.79 compared with the initial values of $1.63-1.82$. In contrast, the ${ }^{8} \mathrm{H}:{ }^{14} \mathrm{C}$ ratios in rats receiving $3.4 \%$ protein decreased, particularly after 10 days of the diet. After 42 days of the diet the ratios in cerebrum, cerebellum, and brain stem were $1.18,1.20$, and 1.17 , respectively, approaching those for skeletal muscle-the major protein depot of the body.

There was very little increment in total brain protein in either group of animals during the 42 days of

Brain Response to Protein Undernutrition 

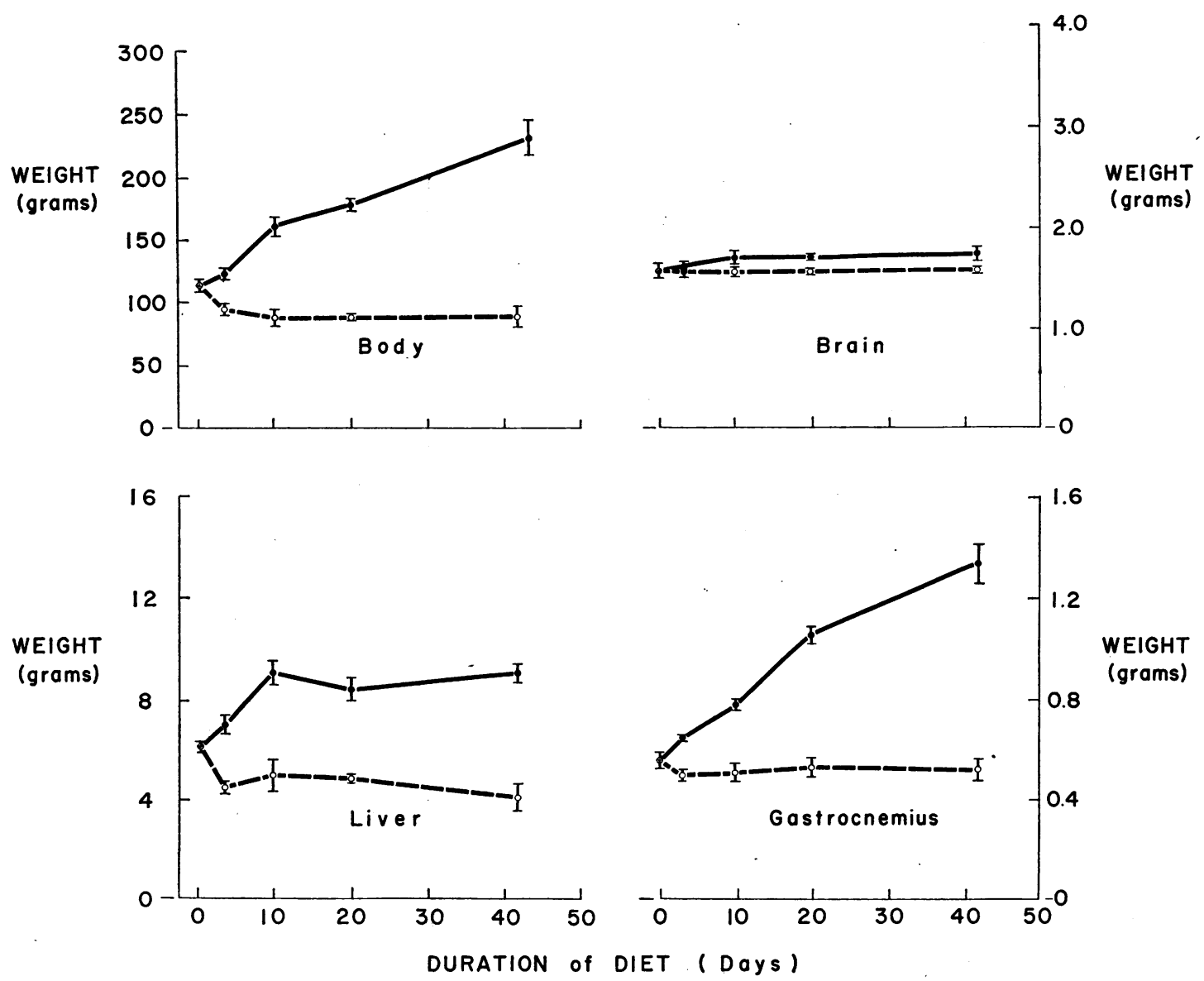

FIgURE 2 Body and tissue weights during administration of diets containing $3.4 \%$ or $26 \%$ protein. The weights of the body, liver, and gastrocnemius muscle diverged due to continued growth of the $26 \%$ protein group and a slight decrease in weights of the $3.4 \%$ animals. There was no change in brain weight in the latter group; the weight of the brains in rats receiving $26 \%$ protein increased only slightly. Means \pm standard errors of the means are indicated.

the dietary regimen. Therefore the rate of protein synthesis must approximate the rate of protein degradation. The maintenance of a distinctively high ${ }^{8} \mathrm{H}:{ }^{14} \mathrm{C}$ in the brain protein of rats receiving the $26 \%$ protein diet suggested that most of the new protein that replaced the catabolized molecules was not synthesized from the products of protein degradation in other tissues but from unlabeled amino acids supplied by the diet. In contrast, the $3.4 \%$ protein diet resulted in the gradual shift of brain ${ }^{8} \mathrm{H}:{ }^{14} \mathrm{C}$ towards that of muscle and other tissues, indicating that newly synthesized brain protein utilized amino acids from degradations of protein elsewhere in the body.

In each of the tissues other than the brain, ${ }^{3} \mathrm{H}:{ }^{14} \mathrm{C}$ remained similar in the two dietary groups at any given age. In skeletal muscle (gastrocnemius) the ratio remained almost unchanged from the initial value of
$1.07 \pm 0.10$ and $0.99 \pm 0.11$, respectively, in the $26 \%$ and $3.4 \%$ protein diet groups. The values for myocardial muscle were almost identical to those of skeletal muscle and also remained stable. In liver and intestinal mucosa, values for ${ }^{8} \mathrm{H}:{ }^{14} \mathrm{C}$ increased from less than 0.5 before 3 days of diet and approached those of skeletal muscle after 10 days of the regimens. Thus, in the animals receiving $26 \%$ protein, all tissues except the brain approached a common ratio, close to that of skeletal muscle. This was to be anticipated if most tissues contribute amino acids to a common circulating pool, which is also drawn upon for synthesis of new protein. However, the presence of long-lived protein components $(11,12)$ and local recycling of amino acids within cells and tissues $(14,15)$ are factors which would favor incomplete mixing of the isotopes with maintenance of some differences in ${ }^{8} \mathrm{H}:{ }^{14} \mathrm{C}$ among tissues. 



FIGURE $3{ }^{3} \mathrm{H}:{ }^{14} \mathrm{C}$ in TCA-precipitable tissue protein during administration of diet containing $3.4 \%$ or $26 \%$ protein. Conditions of isotope administration are described in Methods. In rats receiving the $26 \%$ protein diet, ${ }^{3} \mathrm{H}:{ }^{14} \mathrm{C}$ remained essentially unchanged in the cerebrum, cerebellum, and brain stem; the $3.4 \%$ protein diet resulted in a decrease in ${ }^{3} \mathrm{H}:{ }^{14} \mathrm{C}$, approaching values in other tissues. In other tissues no consistent difference in ${ }^{8} \mathrm{H}:{ }^{14} \mathrm{C}$ between the two diet groups was noted. In gastrocnemius and heart muscle the ratio remained almost constant; in liver and intestinal mucosa it was increased. Counts were less than twice background after 10 days in intestinal mucosa and after 20 days in liver and accurate ratios could not be obtained. Means \pm standard errors of the means are indicated.

Decay of radioactivity in the cerebrum. The rate of decay of radioactivity in the cerebrum between 38 and 77 days of age is shown in Fig. 4. In rats receiving the $26 \%$ protein diet the total number of counts in acid-precipitable protein of the cerebrum decreased in a linear fashion, with almost identical half-times of 22.5 days for ${ }^{8} \mathrm{H}$ and
24 days for ${ }^{14} \mathrm{C}$. By contrast, in rats fed the $3.4 \%$ protein regimen there was a slower loss of each isotope, particularly ${ }^{14} \mathrm{C}$. Indeed there was no significant net decrease in total cerebral ${ }^{14} \mathrm{C}$ during the first 2 days of the $3.4 \%$ protein diet and thereafter the loss of label was slight. The decay results are consistent with the hypothe-

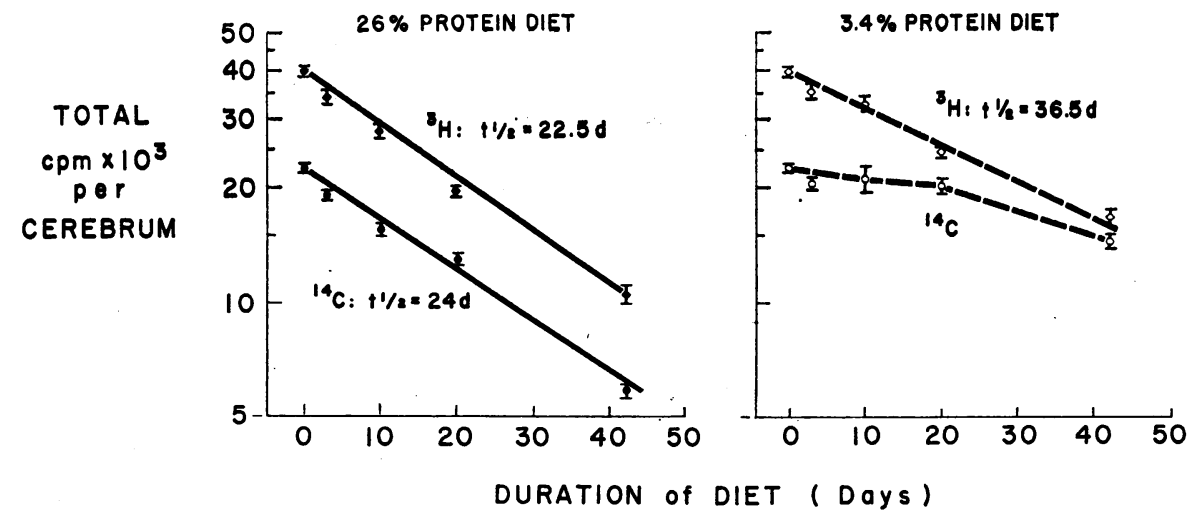

Figure 4 Rate of decay of ${ }^{3} \mathrm{H}$ and ${ }^{14} \mathrm{C}$ in $\mathrm{TCA}$-precipitable protein of the cerebrum during administration of diets containing $3.4 \%$ or $26 \%$ protein. Conditions of isotope administration are described in Methods. Results are expressed as counts per minute in the whole cerebrum. With the $26 \%$ protein diet the rates of decay of ${ }^{8} \mathrm{H}$ and ${ }^{14} \mathrm{C}$ were essentially exponential and similar. The $3.4 \%$ protein diet resulted in a slower decrease in both isotopes, particularly ${ }^{14} \mathrm{C}$, which did not decrease in an exponential manner. Means \pm standard errors of the means are indicated. Half-time $\left(t_{1}\right)$ is expressed in days. 
sis that there is substantial utilization of ${ }^{14} \mathrm{C}$-rich amino acids from other parts of the body for the synthesis of protein in the cerebrum of animals fed the $3.4 \%$ protein diet.

The rate of decay of radioactivity in brain protein is an unreliable index of turnover, particularly in malnourished animals. Reutilization of labeled amino acid for protein synthesis results in overestimation of protein lifespan. Differences in rate of decay as a function of diet are therefore likely to reflect differences in rates of reutilization without necessarily indicating alterations in turnover of brain protein.

\section{ACKNOWLEDGMENTS}

This investigation was supported by grants from the United States Public Health Service, Grant No. AM13897, and the John A. Hartford Foundation. Dr. Dallman is the recipient of a United States Public Health Service Research Career Program Award HE31766.

\section{REFERENCES}

1. McCance, R. A., and E. M. Widdowson. 1962. Nutrition and Growth. Proc. R. Soc. Lond. B. Biol. Sci. 156: 326.

2. Donaldson, H. H. 1911. President's address : studies on the growth of the mammalian nervous system. J. Nerv. Ment. Dis. 38 : 257.

3. Kerpel-Fronius, E., and K. Frank. 1949. Einige Besonderheiten der Körperzusammensetzung und Wasserverteilung bei der Säuglingsatrophie. Ann. Paediatr. 173: 321.

4. Mendes, C. B., and J. C. Waterlow. 1958. The effect of a low-protein diet, and of refeeding, on the composition of liver and muscle in the weanling rat. Br.J. Nutr. $12: 74$.

5. Winick, M., and A. Noble. 1966. Cellular response in rats during malnutrition at various ages. J. Nutr. 89: 300.

6. Graystone, J. E., and D. B. Cheek. 1969. The effects of reduced caloric intake and increased insulin-induced caloric intake on the cell growth of muscle, liver, cerebrum and on skeletal collagen in the postweanling rat. Pediatr. Res. 3: 66.
7. Dobbing, J. 1968. Vulnerable periods in developing brain. In Applied Neurochemistry. A. N. Davison and J. Dobbing, editors. Blackwell Scientific Publications, Ltd., Oxford, England. 287.

8. Harris, J. W., and R. W. Kellermeyer. 1970. In The Red Cell. Harvard University Press, Cambridge. 64.

9. Dallman, P. R., and H. C., Schwartz. 1965. Myoglobin and cytochrome response during repair of iron deficiency in the rat. J. Clin. Invest. 44: 1631.

10. Hinrichs, H. R., R. O. Petersen, and R. Baserga. 1964. Incorporation of thymidine into DNA of mouse organs. Arch. Pathol. 78: 245.

11. Thompson, R. C., and J. E. Ballou. 1956. Studies of metabolic turnover with tritium as a tracer. V. The predominantly non-dynamic state of body constituents in the rat. J. Biol. Chem. 223: 795.

12. Davison, A. N. 1961. Metabolically inert proteins of the central and peripheral nervous system, muscle, and tendon. Biochem. J. 78: 272.

13. Schimke, R. T., R. Ganschow, D. Doyle, and I. M. Arias. 1968. Regulation of protein turnover in mammalian tissues. Fed. Proc. $27: 1223$.

14. Gan, J. C., and H. Jeffay. 1967. Origins and metabolism of the intracellular aminoacid pools in rat liver and muscle. Biochim. Biophys. Acta. 148: 448.

15. Waterlow, J. C., and J. M. L. Stephen. 1968. The effect of low protein diets on the turnover rates of serum, liver, and muscle proteins in the rat, measured by continuous infusion of $\mathrm{L}^{14} \mathrm{C}$ lysine. Clin. Sci. (Oxf.). 35: 287.

16. Munro, H. N. 1964. General aspects of the regulation of protein metabolism. In Mammalian Protein Metabolism. H. N. Munro and J. B. Allison, editors. Academic Press, Inc., New York. 1: 381.

17. Kosterlitz, H. W. 1947. The effects of changes in dietary protein on the composition and structure of the liver cell. J. Physiol. (Lond.). 106: 194.

18. Lowry, O. H., N. J. Rosebrough, A. L. Farr, and R. J. Randall. 1951. Protein measurement with the folin phenol reagent. J. Biol. Chem. 193: 265.

19. Benton, J. W., H. W. Moser, P. R. Dodge, and S. Carr. 1966. Modification of the schedule of myelinization in the rat by early nutritional deprivation. Pediatrics. 28: 801 .

20. Enesco, M., and C. P. Leblond. 1962. Increase in cell number as a factor in the growth of the organs and tissues of the young male rat. J. Embryol. Exp. Morph. 10 : 530 . 